\title{
Even the Western States Have Rights to Act Culturally During Refugee Crisis
}

\author{
Ozlem* \\ Indiana University Bloomington, USA \\ Submission: April 09, 2018; Published: June 12
}

, 2018

Abstract

The failure of the Western States in responding the current refugee crises is a matter of debate in the World as they are often viewed as the delegates of universalism. Many European countries reacted surprisingly to accept refugees on their lands and preferred to accept refugees with cultural, social or religious similarities. On the other hand, the Middle Eastern States have implemented relatively successful strategies to host refugees. This paper discuss the reasons for the Western States' failures and the Middle Eastern States' success in accepting refugees through re-interpreting the historical and anthropological explanations.

Keywords: Cultural-responses; Refugee Crisis; Refugee Convention; Humanitarianism; Refugee Accommodation Approaches; Crisis; Social networks; Reciprocity; Situational responses; Hierarchy; Liminality; Myths; Historical; Anthropological

\section{Introduction}

After the Syrian Civil War, refugee exodus gained unprecedented momentum in the world. As Goodwin-Gill [1] stated, this situation, on the one hand, required the signatory countries of the 1951 Refugee Convention on the Status of Refugees to protect and welcome refugees, and, on the other hand, caused a breach of original liability of the legal instruments regarding refugee protection. The reaction of the Western States against the Syrian refugee influx proves the non-uniformity of the widely accepted legal theory to exercise refugee protection. This situation reveals that the current legal instruments remain imperfect. On the other hand, both locals and refugees in the neighboring countries of Syria reacts surprisingly to assist a massive influx of displacement without having the guidance of standards suggested in the current legal instruments.

\section{New Solutions to Host Refugees of Appropriation of the Historical Responses}

Concerning the inadequacy of legal and political approaches, Alexander Betts in his 2016 TED talk titled 'Our refugee system is failing. Here is how we can fix it" highlights the failure of signatory countries of the 1951 Refugee Convention in admitting people on their lands. In this speech, Betts is not simply trying to criticize the failure of the Western States' immigration policies. He intends to offer geographically applicable and communitybased solutions through market opportunities and mobility. In detail, these solutions are a. Providing economic opportunities in the host country.

b. Employing refugees to create mutual benefits.

c. Considering the needs and capabilities of local and refugee communities, and

d. Humanitarian visas rather than status determination. Undoubtedly, his solutions look promising, but are they new solutions or appropriation of historical and geographical knowledge?

\section{The Development of Historical and Geographical Knowledge}

Some scholars explains that many nations in the Middle East used their historical and geographical knowledge to accommodate displaced people on their lands. People have developed strategies to cope with the violent and cruel aspects of displacement throughout the history. Chatty [2] explains the reasons for people's behaviors in the past from a historical lens and provides meaningful explanations through analyzing the linguistics, religious, and ethnic grounds of the local and displaced people in the Middle East. According to her analysis, the First World War resulted in the end of pluralism and increased the tension between majority and minority groups. People fled because of wars, famine, terrorist attacks and civil unrest during the collapse of the Ottoman Empire. Lack of states' 
protection and uncertainty of remedial solutions led people to create their livelihoods through establishing connections and relying on their shared beliefs.

Chatty $[2,3]$ mentions that historical events and cultural similarities prepare a background for the continuous community support mechanisms during displacements, particularly in the Middle East. People have felt obliged to help refugees to protect their social fabric and environment. Colson [4], on the other hand, analyzes the locals and refugees' responses from an anthropological perspective. Her examples prove that people have used concepts and norms such as social networks, reciprocity, situational responses, hierarchy, liminality, and myths as validation of their actions during displacements. Chatty's \& Colson's [2-4] approaches are different, but their arguments show similarities regarding local and refugee communities' self-sufficient strategies to survive during displacement and resettlement. With that said, Betts's solutions to rely on such self-reliant norms and concepts in one-way or another are not new suggestions but are the discovery of local humanitarianism as Malkki stated.

Historical and anthropological explanations show that host communities and refugees' reactions in neighboring countries to deal with resettlement is not unexpected. Communities in the Middle East use their accumulated historical, geographical, political and cultural knowledge of hosting forcibly displaced people. Their humanitarian assistance, therefore, generates so-called better results as the solutions come from local and refugee communities, and both locals and refugees share a similar understanding of coping with displacement. In other words, locals and refugees in the Middle East share a historical consciousness of not being able to return to the place where they once called home so that they develop a sense of building a new home in the host country.

\section{Humanitarian Assistance Today Inspired by the Past Practices}

Knowing the realistic scenarios of displacement, countries such as Turkey, Lebanon and Jordan have taken a great deal of responsibility to host refugees. Today, Turkey hosts 3,567,130 Syrian nationals $[5,6]$, whereas the number of Syrians reaches 991,917 in Lebanon and 659,063 Jordan [6]. When the population of each country taken into consideration, Jordan with 10 million citizens and Lebanon with 6 million citizens considerably experiences more difficulties than Turkey [7].

This being the case, reminding some of the political and social mechanisms in these countries is helpful to notice the connections between past and present. Turkey, as the county with the highest number of refugees, applied open door policy for Syrian nationals [8] and spent 6,000 millions of dollars to host refugees without international support [9]. From the beginning of the crisis, Turkey uses the term "guests" for Syrian nationals, and the government emphasizes the necessity of showing hospitality by utilizing the Ottoman legacy as an asset [10]. In presenting Syrian nationals as guests, the intention is to highlight the fact that Syrians and Turks were part of the same empire and had religious, cultural, and historical commonalities. Lebanon and Jordan practice a discourse around the notion of brotherhood and kinship. Syrian nationals resettle in the regions where they have relatives [11]. Mackreath's [12] essay on the role of Lebanese women in assisting Syrian women highlights that closer affiliation help people to be connected to each other. When the sectarian problems are considered, Lebanese community chooses the safest and less problematic connections with the Syrian community.

Given the above explanations, countries neighboring Syria implements alternative anthropological approaches to accommodate refugees. The use of anthropological approaches may be related to the lack of legal instruments for regulating migration, but people's robustness to create social spaces in conflict zones has always been a reality. Anthropologists bring the light upon this reality and raise awareness on the necessity of studying not just refugees but also the cultural, political, religious, and social surroundings around them [2,3,13-15]. Social actors and their understandings of their interactions with their surroundings show that single solutions and top-down approaches are not useful to respond refugee crisis. In relation to the ineffectiveness of top-downand standardized approaches, the lack of core conceptual binaries in the legal frameworks such as "place and space, home,and homeland, territoriality and liminality, belonging and identity, social networks and capital ...". [3] explains the failure of the Western States. However, Western states should not be blamed for its failure, but for using the same legal framework, which is 1951 Refugee Convention as a solution for all forced migration scenarios.

\section{Europeans as Socio-Cultural Groups Instead of Delegates of Universalism}

Indisputably, 1951 Refugee Convention has worked effectively to solve the issues of massive and violent displacements in Europe after the Second World War. Later on, geographical limitations were removed from the convention in 1967 for resolving refugee crisis happening in other parts of the world. The removal of geographical limitations does not make the document applicable to all cultural contexts because the convention was designed for responding displacement in Europe and the people with similar backgrounds. In other words, it was a regional and cultural instrument.

This legal instrument was effective in responding situations when people had similar cultural and political backgrounds [16]. However, it currently fails to provide satisfactory solutions when reconciling issues between people from different social, religious and cultural backgrounds even in the same geographical locations. For example, in Bosnia and Herzegovina, international organizations did not adequately address peace 
building and repatriation process among three different ethnic and religious groups because of ignoring the Bosnian context and history [17]. Stefansonn's [18] research on Bosnian refugee return further explains that the impact of failures on creating a livelihood and sense of home continues because the solutions are not formulated through building the relationship between the local and national environment. Therefore, it would be unreasonable to expect that this legal instrument would create long-lasting solutions to the problems in other regions when it fails to respond to the crisis happening in Europe adequately.

The Western States' responses to Syrian Refugee Crisis also strengthen the argument that people in Europe still use the cultural, religious, political, and social grounds when welcoming refugees from different cultural contexts. For example, Slovakia and Hungary announced that they prefer to accept only nonMuslim refugees from Syria, but they are signatory countries of the convention [19]. Examples can be increased, yet the denial of the imperfection of the legal instruments will solely support the legitimation of extraordinary responses of the Western States [20], which eventually leads politicians to justify their violation of human rights and use refugees as political chips in negotiating with bordering states to keep refugees away from Europe [2123]. Therefore, Europeans' reaction to the European Migration Crisis and Syrian Refugee Crisis are not surprising because the discourse that introduces Europeans as the delegates of universalism leaves no room for them to exercise their cultural and social norms and values.

\section{Conclusion}

Europe like the other parts of the world is cultural geography with its differences. Europe and the process of managing migration crisis in this region should be in the interests of anthropologists. European's discriminative political and cultural reactions in refugee crises are unacceptable, but without understanding them as socio-cultural groups in particular regions, the world only produce a false image of Europeans. Unquestionably, Europe should share the burden with the other countries, but they also should have the flexibility to arrange the most suitable accommodations based on their cultural values on the conditions of treating people with dignity and respect. In doing so, anthropological approaches can help inform forced migration policies by providing culturally appropriate, accurate and applicable information on people's and states' experiences of displacement, resettlement, and adaptation. Europe is failing because the surrounding discourse takes their voices away to respond refugee crisis based on their cultural and social capabilities. By following the same legal frameworks as universal guidelines, we can only prove the uselessness of the top-down approaches. The more the policymakers attempt to universalize the rules, the more conflicts and misunderstandings people of the Western and Middle Eastern States have. Middle Eastern states have their flexibility to rely on their cultural norms, so should Western states.

\section{References}

1. Kohl P (1998) Nationalism and archaeology: constructions of nations and the reconstructions of the remote past. Annual Review of Anthropology 27: 233-46.

2. Trigger B (1989) A History of Archaeological Thought. Cambridge University Press, Cambridge, USA.

3. Chakrabarti DK (1997) Colonial Indology: Sociopolitics of the Ancient Indian Past. Delhi, India.

4. Asher CB, Metcalf TR (1994) Introduction. In pp 1-12 Perceptions of South Asia's Visual Past edited by Asher and Metcalf, Oxford \& IBH, New Delhi, India.

5. Majumdar RC (1961) Nationalist historians; In: Philips CH(Eds.),Historians of India, Pakistan and Ceylon; Oxford University Press, London, UK, pp. 416-28.

6. Tagore RN (1934) Foreword in Journal of the Greater India Society.

7. Basa KK (1998) Indian writings on early history and archaeology of Southeast Asia: A historiographical analysis. Journal of the Royal Asiatic Society London, UK 8(3): 395-410.

8. Chatterjee BR (1939) Recent advances in Kambuja studies. Journal of the Greater India Society 6(2): 138-45.

9. Majumdar RC (1927) Ancient Indian Colonies in the Far East, Vol. 1. Punjab Sanskrit Book Depot, Lahore.

10. Majumdar RC (1944) Hindu Colonies in the Far East. General printers and Publishers, Calcutta, India.

11. Nilakanta Sastri KA (1941) Srivijaya. Bulletin de l'Ecole Francaise d'Extreme-Orient XL(2): 239-310.

12. Gangoly OC (1927) The Art of Java. Rupam, Calcutta, India.

13. Basa KK (1991) The Westerly Trade South East Asia with Special Reference to Glass Beads. University of London, UK.

14. Basa KK (2007) Social Theory and Indian Archaeology: A Historiographical Study during the Colonial Period. Presidential address, Archaeology Section, Indian History Congress $\left(67^{\text {th }}\right.$ session, Kozhikode).

15. Coedes G (1968) The Indianised States of South East Asia. East and West Center Press, Hawaii, USA.

16. Mookerji RK (1954) The Fundamental Unity of India. Bharatiya Vidya Bhavan, Bomnay,Maharashtra, India. 


\section{Your next submission with Juniper Publishers} will reach you the below assets

- Quality Editorial service

- Swift Peer Review

- Reprints availability

- E-prints Service

- Manuscript Podcast for convenient understanding

- Global attainment for your research

- Manuscript accessibility in different formats

( Pdf, E-pub, Full Text, Audio)

- Unceasing customer service

Track the below URL for one-step submission https://juniperpublishers.com/online-submission.php 